\title{
COVID-19 Hastalığında Fizyoterapi ve Rehabilitasyon: Bir Derleme Makalesi
}

\author{
Hüsniye Merve KARAAĞAÇ*, Ali KARAAĞAÇ***
}

\begin{abstract}
Öz
COVID-19, kişilerde öncelikli olarak solunumsal fonksiyon bozukluklarına yol açan, bunun yanı sıra psikolojik, fiziksel ve sistemik işlev bozukluklarına neden olan bulaşıcılık oranı yüksek olan bir hastalıktır. Hastaların büyük bir kısmını 20-60 yaş aralığındaki bireyler oluşturmaktadır ve erkeklerde görülme sıklığı kadınlara göre daha fazladır. Literatürde COVID-19 hastalığında akut ve post-akut dönemde uygulanacak olan fizyoterapi ve rehabilitasyon uygulamaları ile ilgili çok az bilgi bulunmaktadır. Mevcut veriler, akut dönemde fizyoterapi ve rehabilitasyon uygulamalarının yarar ve riskler gözetilerek bireysel temelli olarak yapılmasını ortaya koymaktadır. Hastalığın evresine göre hastanın klinik durumu ve rehabilitasyon ihtiyaçları değişmektedir. Fizyoterapi ve rehabilitasyon programına, multidisipliner yaklaşımla karar verilmeli ve hastanın durumu stabilleştiğinde, belirlenen hedefler doğrultusunda uygun olan yaklaşımlar hastanın klinik durumu gözetilerek uygulanmalıdır. Bu derleme, COVID-19 hastalığı hakkında hem fizyoterapistlere yol göstermek hem de hastalığın şiddetine göre uygulanabilecek olan fizyoterapi ve rehabilitasyon yöntemleri konusunda bilgi vermek amacıyla yazılmıştır.
\end{abstract}

Anahtar kelimeler: COVID-19, fizyoterapi ve rehabilitasyon, pulmoner rehabilitasyon.

\footnotetext{
Derleme Makale (Review Article)

Geliş / Received: 09.01.2021 \& Kabul / Accepted: 31.03.2021

DOI: https://doi.org/10.38079/igusabder.857159

* Öğr. Gör., İstanbul Gelişim Üniversitesi, Sağllk Hizmetleri Meslek Yüksekokulu, Fizyoterapi

Programı, İstanbul, Türkiye, E-posta: hmkaraagac@gelisim.edu.tr

ORCID https://orcid.org/o000-0003-2999-1461

** Öğr. Gör., İstanbul Gelişim Üniversitesi, Sağlık Hizmetleri Meslek Yüksekokulu, Fizyoterapi

Programı, İstanbul, Türkiye, E-posta: akaraagac@gelisim.edu.tr

ORCID https://orcid.org/o000-0002-4327-7347
} 


\title{
Physiotherapy and Rehabilitation in COVID-19 Disease: A Review Article
}

\begin{abstract}
COVID-19 is a highly contagious disease that primarily causes respiratory dysfunction in individuals, as well as psychological, physical and systemic dysfunctions. Most of the patients are between the ages of 20-60 and its incidence is higher in men than in women. In the literature, there is very little information about physiotherapy and rehabilitation applications to be applied in the acute and post-acute period in COVID-19 disease. Existing data reveal that physiotherapy and rehabilitation applications in the acute phase should be performed as individual-based, by considering the benefits and risks. The clinical condition and rehabilitation needs of the patient vary according to the stage of the disease. Physiotherapy and rehabilitation program should be decided with a multidisciplinary approach and when the patient's condition stabilizes, appropriate approaches should be applied considering the clinical condition of the patient in line with the determined goals. This review has been written to both guide physiotherapists about COVID-19 disease and to provide information about physiotherapy and rehabilitation methods that can be applied according to the severity of the disease.
\end{abstract}

Keywords: COVID-19, physiotherapy and rehabilitation, pulmonary rehabilitation.

\section{Giriş}

Aralık 2019'un sonlarında, Çin'deki Wuhan kentinde bulunan bir deniz ürünleri toptan satış pazarında ateş, kuru öksürük, yorgunluk ve bazen mide-bağırsak semptomları ile karakterize gizemli bir viral pnömoni hastalı̆̆ı meydana gelmiştiri i Illk olgular, Aralık 2019'da bildirilmiş ve pazardaki personelin yaklaşık \%66'sını içermiştir². Daha sonra salgın önce Avrupa olmak üzere kısa sürede tüm dünyayı etkisi altına almıştır. 7 Ocak 2020 tarihinde bu virüs, insanlarda daha önce tespit edilmeyen yeni bir Koronavirüs türü (SARS-CoV-2) olarak tanımlanmıştır³. Ülkemizdeki ilk COVID-19 vakası 11 Mart 2020 tarihinde görülmüş4 ve 12 Mart 2020 tarihinde Dünya Sağllk Örgütü (DSÖ) bu salgını pandemi ilan etmiştir 3 .

Hastalı̆̆ın klinik görünümü inkübasyon sürecini takiben olası ateş, inatçı kuru öksürük, nefes darlığı ve miyaljiyi içerir. Nadir ancak yaşamı tehdit eden vakalar, pnömoni ve Akut Solunum Sikıntısı Sendromu (Acute Respiratory Distress Syndrome, ARDS) ile sonuçlanır. Hastalık Kontrol Merkezi, enfekte kişilerin \%80’inin yalnızca birkaç tedavi müdahalesi gerektiren hafif veya orta derecede hastalık yaşayacağını, \%20'sinin ise 
yoğun tıbbi bakım gerektirecek şiddette etkileneceğini öngörmektedir. Kesin vaka ölüm oranı tahmini zor olsa da, DSÖ \%3,4'lük bir oran bildirmektedir5.

COVID-19'dan kurtulanların sağlı̆̆ı, sosyal ihtiyaçları ve rehabilitasyonu ile ilgili henüz çok az bilgi bulunmaktadır. Diğer ülkelerde post-akut bakım gereksinimi olan COVID-19 hastalarının oranı ve bu hastaların uzun vadeli sonuçları ile ilgili sınırlı veri vardır ${ }^{6}$. Buna karşın yoğun bakımda uzun süre kalan hastalarda, yoğun bakım sonrası fiziksel, bilişsel ve psikolojik bozukluklar gelişebildiği bilinmektedir. Akut Solunum Sıkıntısı Sendromu olan COVID-19’lu bireylerde uyku yoksunluğu, kemik hastalığı (artmış kemik demineralizasyonu), susuzluk, deliryum ve ağrı gelişebilir. Yoğun bakımda daha uzun süre kalan hastalarda ise kas kaybı, nöropati, mobilite kaybı, işlev kaybı ve güçsüzlük gelişme olasılığı daha yüksektir. Fazla bilinmeyen yoğun bakım sonrası sendromu, özellikle ARDS, uzamış mekanik ventilasyon ihtiyacı ve sepsis görülen hastalarda, uzun vadeli sonuçların kötü olması ile ilişkili bulunmuştur ${ }^{6,7}$. Henüz, bu yeni tip koronavirüsün uzun vadede fiziksel, fizyolojik ve psikolojik sonuçlarının bilinmemesiyle birlikte, influenza A ( $\left.\mathrm{H}_{7} \mathrm{N9}\right)$, Ciddi Akut Respiratuvar Sendrom (Severe Acute Respiratory Syndrome-SARS), Domuz Gribi (H1N1) ve Orta Doğu Solunum Sendromu (Middle East Respiratory Syndrome-MERS) salgınları ile ilgili literatüre bakıldığında, pulmoner fonksiyonda daha uzun süreli devam eden azalmayı, azalmış yaşam kalitesini ve azalmış fiziksel fonksiyonu gösteren bazı kanıtlar vardır,9.

$\mathrm{Bu}$ bilgiler ışığında bu derlemenin amacı, COVID-19 teşhisiyle hastaneye yatırılan hastaların tedavisinde fizyoterapistlere yol göstermek, COVID-19 hastalarının hastane tedavisi sırasında ve sonrasında rehabilitasyonlarını genel bir bakış açısıyla açıklamaktır.

\section{COVID-19}

COVID-19, kişilerde öncelikli olarak solunumsal fonksiyon bozukluklarına yol açan, bunun yanı sıra psikolojik, fiziksel ve sistemik işlev bozukluklarına neden olan bulaşıcılık oranı yüksek olan bir hastalıktır. COVID-19, temelde bir coronavirüs olan SARS-CoV2'nin yol açtığı bir solunum yolu enfeksiyonu olarak bildirilmektedir. SARS-CoV-2 virüsünün genetik sekansı, SARS virüsününkine oldukça benzerlik göstermektedir ve bir Betacoronavirüs çeşididir3.

Güncel epidemiyolojik verilere dayanarak COVID-19'un inkübasyon süresinin 1-14 gün olduğunu, genel olarak 3-7 gün arasında bulaştırıcılığının fazla olduğunu ve latans 
dönemde de bulaşıcılığının olduğu söylenebilir ${ }^{10}$. Yaşlı ve eşlik eden hastalıklara sahip olan bireyler, enfeksiyona karşı daha duyarlı olmakla birlikte ARDS ve sitokin fırtınasıyla ilişkili olarak görülebilecek ciddi sonuçlara maruz kalabilirler ${ }^{11}$. Yapılan bir metaanalizde en çok komorbiditenin kardiyovasküler hastalıklar, hipertansiyon ve diyabet olduğu belirtilmiştir ${ }^{12}$.

Enfeksiyon, sıklıkla asemptomatik veya semptomatik bireylerden hapşırma ya da öksürme esnasında oluşan damlacıklar aracılığıyla bulaşmaktadır. Hastalık, hastalar semptom göstermeye devam ettiği süreç boyunca hatta klinik iyileşme sürecinde de bulaşıcı olabilmektedir. Bu damlacıkların solunmasıyla ya da kontamine olan yüzeylerle temas edildikten sonra ağız, burun ve göz bölgesine dokunulması sonucu enfeksiyon bulaşmaktadır ${ }^{13}$.

Güncel verilere dayanarak, gebelikte anneden fetüse transplasental bir bulaş bildirilmemiştir. Fakat doğum sonrasında bulaşa bağlı olarak yenidoğan hastalığı literatürde tanımlanmıştır ${ }^{14}$.

\section{Klinik Özellikler}

Çin'de yayınlanmış olan bir meta-analizde, hastaların büyük bir kısmının 20-60 yaş arası bireylerden oluştuğu, erkeklerde kadınlara oranla enfeksiyon insidansının daha yüksek olduğu ve hastalık başlangıcından semptomlar ortaya çıkana kadar ortalama 5 günlük bir süre olduğu ifade edilmiştir. Hastalık şiddetinin olguların \%81,4’ünde hafif düzeyde, \%13,9'unda şiddetli düzeyde ve \%4,7'sinde ise kritik düzeyde olduğu belirtilmiştir ${ }^{15}$.

Sağlık Bakanlığı'nın açıklamış olduğu verilere dayanarak, ülkemizde hastaların yoğun bakımda tedavi edilme oranının \%3,5 seviyesinde olduğu ve bu hastaların \%63,7'lik bir bölümünün entübe edildiği bilinmektedir ${ }^{16}$. Dünya Sağlık Örgütü’nün klinik sınıflandırmasının sırasıyla; hafif hastalık, pnömoni, ciddi pnömoni, ARDS, sepsis ve septik şoka kadar geniş bir yelpazede olduğu görülmektedir ${ }^{17}$.

Hastalığın yaygın klinik semptomları arasında boğaz ağrısı, ateş, baş ağrısı, sıklıkla kuru öksürük, kas ağrısı, yorgunluk ve nefes darlığı bulunmaktadır ${ }^{18}$. Ek olarak bulantı, diyare, kusma, gastrointestinal kanama, karın bölgesinde ağrı gibi semptomlar gözlenebilir. Yapılan bir çalışmada; yetişkinlerde anoreksinin, yetişkin ve çocuklarda diyarenin ve çocuklarda kusmanın en çok gözlenen sindirim sistemi semptomları olduğu belirtilmiştir ${ }^{13}$. Tat alma problemi ve anosmi ise ilk belirti olarak kendini gösterebilir ${ }^{19}$. 
Konjuktivit, COVID-19 hastalarında, düşük yüzdelerde olmakla beraber, gözlenebilir ${ }^{20}$. Literatürde bir meta-analizde görülen en sık semptomların ateş, nefes darlığı ve öksürük olduğu belirtilmiştir ${ }^{12}$.

Hastaların büyük bölümünde komplikasyonsuz ya da hafif düzeyde hastalık görülürken, ortalama \%14'lük kesimde oksijen desteği ve hastaneye yatış ihtiyacı gelişmekte olup \%5'lik kesimde yoğun bakıma alınma ihtiyacı görülmektedir. Ciddi vakalarda, COVID-19 sepsis ve septik şok, akut gelişen böbrek ve kalp hasarı da dahil çoklu organ yetmezliğiyle komplike olabilmektedir3.

\section{Tanı}

Klinik olarak tanı konulması, gerçek zamanlı olarak Polimeraz Zincir Reaksiyonu (PCR) testiyle boğaz ve burundan alınan sürüntü örneklerinde ya da diğer solunum yolundan alınan örneklerde nükleik asitin tespit edilmesi ile gerçekleşirir ${ }^{11}$. Genellikle laboratuvardan elde edilen bulgular non-spesifiktir. Sıklıkla akciğer grafisinde çift taraflı olarak infiltrasyon gözlenir, fakat erken dönemde akciğer grafisi sonucu normal olabilmektedir. Bilgisayarlı tomografi (BT) ile görüntüleme sonucu infiltratlar, alt segment konsolidasyonu ve buzlu cam opasiteleri gözlenebilir²1.

\section{COVID-19 Hastalığında Fizyoterapi ve Rehabilitasyon}

Mevcut veriler, akut dönemde fizyoterapi ve rehabilitasyon uygulamalarının yarar ve riskler gözetilerek bireysel temelli olarak yapılmasının gerekliliğini ortaya koymaktadır ve bu dönemdeki fizyoterapi ve rehabilitasyon uygulamaları mobilizasyon ve pozisyonlama ile sınırlı kalmaktadır ${ }^{17,22}$. Güncel protokol ve rehberler, bu dönemde solunum egzersizlerinin, havayolunu temizleme tekniklerinin, solunum kaslarının eğitiminin, yardımcı cihazların kullanımı ile gerçekleştirilen uygulamaların ve egzersiz eğitiminin uygulanmasının uygun olmadığını bildirmektedir²2-25.

COVID-19'lu hastalarda siklıkla kuru prodüktif olmayan öksürük ve solunum yolunun alt bölgesinde pnömonit gözlenir ${ }^{22,23}$. Olgularda akut dönemde havayolunda sekresyon miktarı oldukça azdır. Bu sebeple, COVID-19'da havayolunu temizleme teknikleri kullanımı gerekmemektedir²2-24.

Hafif hastalıkta: Enfeksiyonun hafif seviyede görüldüğü yaklaşı \%8o'lik kesimde, ateş, öksürük, kas ve veya eklem ağrısı, nazal konjesyon ve boğaz ağrısı semptomları 
görülmektedir. Havayolunda sekresyon miktarının oldukça az olduğu görülür. Buradan yola çıkarak solunum fizyoterapisinin ve rehabilitasyon uygulamalarının hastalığın seyrinin üzerinde etkisinin olduğu söylenemez. Hafif hastalık olan olgularda solunum fizyoterapisi endike olmamakla birlikte hastaların mümkün olabildiği ölçüde aktif kalmasının uygun olduğu söylenebilir.

Pnömonide: Bu olgularda mümkün olabildiği ölçüde mobilizasyon uygundur. Yataktan kalkma aktiviteleri, yatak içi egzersizler, üst ve alt ekstremitede egzersizler, oturmada denge eğitimi, ayakta duruş ve ambulasyon uygulanabilir ${ }^{22}$. Uygulanacak olan egzersiz ve mobilizasyonlar, fizyoterapistlerin güvenliği ve etkin olarak çalışabilmesi bakımından, broşür ve tele-rehabilitasyon uygulamalar (eğitim videoları, telefonla görüşme, görüntülü görüşme) aracılığıyla gerçekleştirilebilir. Yapılan uygulamalar, hastaların sekresyonlarını hareketlendirebilir ve öksürük ile balgam çıkarmalarına yardımcı olabilir. Uygulamalar hastalara iki metre mesafeden daha yakında olunmasını gerektiriyorsa mutlaka kişisel koruyucu ekipman kullanılmalıdır. Hastaların maske takması, izolasyon önlemlerinin ve kurallarının uygulanması çok önemlidir ${ }^{26}$.

Ciddi pnömonide: Şiddetli enfeksiyon nedeniyle hastaneye yatışı yapılan hastalarda ciddi pnömoni olduğu görülmektedir. Olguların bir bölümünde akut hipoksemik solunum yetersizliğiyle karakterize olan ARDS, septik şok, sepsis, çoklu organ yetersizliği görülebilmektedir. Yoğun bakım seviyesinde takibi yapılan bu hastalarda invaziv mekanik ventilasyon ve entübasyon gereklidir,17,22,27.

Sıklıkla ARDS ve pnömonide, hastalarda solunum işini ve solunum sıkıntısını artırmayacak, yoğun bakımda günlük pratikte uygulanan $30-45^{\circ}$ yüksek yatış pozisyonu ve yüzükoyun pozisyonu faydalı olmaktadır ${ }^{17}$. Yoğun bakım ünitesinde kazanılmış zayıflığı bulunan ve fonksiyonel kayıp yaşayan olgularda, klinik stabilite ve sedasyon izin verdiği zaman pasif ve aktif olarak eklem hareket açıklık egzersizleri ve mobilizasyonlar uygulanabilir ${ }^{17,22,23,25 . ~}$

Genel olarak COVID-19'lu hastalarda hastane döneminde uygun olan (stabil ve rehabilitasyona engel durumu olmayan) hastalara yapılacak fizyoterapi ve rehabilitasyon uygulamaları planlanmadan önce hastalar detaylı bir şekilde değerlendirilmeli ve hedefler belirlenmelidir. Sonrasında uygun zamanda, hedefler doğrultusunda bireye 
özgü rehabilitasyon yaklaşımları planlanmalıdır. COVID-19'lu hastalarda olası hedefler ve bu hedeflere uygun rehabilitasyon yaklaşımları Tablo 1'de verilmiştir.

Tablo 1. COVID-19 hastalarında hedefler doğrultusunda yapılabilecek fizyoterapi ve rehabilitasyon uygulamalari ${ }^{26,28}$

\begin{tabular}{|c|c|}
\hline Hedef & $\begin{array}{l}\text { Fizyoterapi ve Rehabilitasyon } \\
\text { Uygulaması }\end{array}$ \\
\hline Solunum yollarının açık tutulması & \multirow{3}{*}{$\begin{array}{ll}\text { - } & \text { Pozisyonlama } \\
\text { - } & \text { Mobilizasyon } \\
\text { - } & \text { Postural drenaj teknikleri } \\
\text { - } & \text { Diğer hava yolu temizleme teknikleri } \\
\text { (mekanik yardımlı öksürme cihazları, } \\
\text { aktif solunum teknikleri döngüsü, } \\
\text { otojenik drenaj, zorlu ekspirasyon } \\
\text { tekniği, öksürme, manuel yardıml } \\
\text { öksürme, manuel hiperinflasyon) } \\
\text { - Pozitif ekspiratuar basınç (PEP) } \\
\text { - Yüksek frekanslı göğüs duvarı } \\
\text { ossilasyonları (Vest) ve diğer ossilatuar } \\
\text { cihazlar }\end{array}$} \\
\hline Sekresyon birikiminin önlenmesi & \\
\hline $\begin{array}{l}\text { Ventilasyonun ve oksijenasyonun } \\
\text { düzeltilmesi }\end{array}$ & \\
\hline $\begin{array}{l}\text { Diyafram ve diğer solunum kaslarının } \\
\text { pozisyon ve fonksiyonunun } \\
\text { geliştirilmesi }\end{array}$ & \multirow{3}{*}{$\begin{array}{ll}\text { - } & \text { Respiratuvar ve fiziksel egzersiz eğitimi } \\
\text { - } & \text { Solunum stratejileri (solunum kontrolü) } \\
\text { - } & \text { Diyafragmatik solunum/derin solunum } \\
\text { egzersizleri } \\
\text { - } & \text { Pursed-lip solunumu } \\
\text { - } & \text { İnsentif spirometre } \\
\text { - } & \text { Solunum kas eğitimi }\end{array}$} \\
\hline Solunum hızının azaltılması & \\
\hline $\begin{array}{l}\text { Dispnenin azaltılması ve gevşemenin } \\
\text { sağlanması }\end{array}$ & \\
\hline $\begin{array}{l}\text { Akciğer bozukluğu sonucu gelişen } \\
\text { postüral deformitelerin saptanması, } \\
\text { önlenmesi ve/veya düzeltilmesi }\end{array}$ & \multirow{3}{*}{$\begin{array}{ll}\text { - } & \text { Göğüs kafesine germe veya manuel } \\
\text { mobilizasyon } \\
\text { - } & \text { Egzersiz eğitimi } \\
\text { - } & \text { Sedatize olan ve klinik olarak stabil } \\
& \text { olmayan olgularda mobilizasyon } \\
\text { - } & \text { Pasif ve aktif mobilizasyon }\end{array}$} \\
\hline $\begin{array}{l}\text { Göğüs hareketliliğinin artırılması veya } \\
\text { azalmasının önlenmesi }\end{array}$ & \\
\hline $\begin{array}{l}\text { Enduransı ve genel egzersiz toleransını } \\
\text { geliştirmek }\end{array}$ & \\
\hline $\begin{array}{l}\text { Kayg1, depresyon ve anksiyeteyi } \\
\text { basklamak }\end{array}$ & - Psikososyal destek \\
\hline $\begin{array}{l}\text { Fonksiyon kaybını ve yaşam kalitesini } \\
\text { düzeltmek }\end{array}$ & $\begin{array}{ll}\text { - } & \text { İş ve uğraşı tedavisi } \\
\text { - } & \text { Hasta eğitimi ve sigara bıraktırma } \\
\text { - } & \text { Nutrisyonel değerlendirme ve destek }\end{array}$ \\
\hline
\end{tabular}




\section{COVID-19 Hastalığının Post-Akut Döneminde Fizyoterapi ve Rehabilitasyon}

COVID-19 kaynaklı pnömoni ve ARDS geçiren hastalarda, post-akut dönemde fizyoterapi ve rehabilitasyon ihtiyacı net olarak bilinmemektedir. Ancak SARS ve H1N1 gibi diğer viral enfeksiyonlardan edinilen bilgilere dayanarak, akut evre ve yoğun bakım süreçlerinin sonunda kas fonksiyonu ve kas kütlesinin kaybı, kontraktür, nöropati ve myopatiler ve yoğun bakımda edinilmiş güçsüzlük gibi fiziksel fonksiyonda ve solunumda kayıplar; post travmatik stres sendromu, depresyon ve anksiyete gibi kognitif ve emosyonel fonksiyonlarda bozulmalar ve yaşam kalitesinde azalma olabileceği söylenebilir ${ }^{23,25,29-36}$.

Hipoksemik solunum yetmezliğinin ve etkilerinin sonucunda hastanın toparlanma süreci kişiden kişiye farklılık gösterebilir ${ }^{29}$. Komorbiditelere sahip hastalarda sürecin bir miktar daha uzayabilmesiyle birlikte akut solunum yetmezliği teşhisini takiben görülen fiziksel fonksiyonlardaki en büyük değişiklikler, taburcu edildikten sonra iki ay içerisinde ortaya çıkmaktadır25,35. COVID-19 enfeksiyonu atlatan hastalarda bu fazda, fiziksel fonksiyonda ve solunumda görülen kayıplar, emosyonel ve kognitif sorunlar sebebiyle fizyoterapi ve rehabilitasyon yaklaşımlarına ihtiyaç doğabilecektir ${ }^{23,25,37}$. Bunun yanı sıra akut COVID-19 hastalığından iyileşen fakat hastalık öncesindeki fonksiyonellik ve aktivite düzeylerine geri dönmede sorun yaşayan, yüksek kırılganlığa sahip hastalarda da fizyoterapi ve rehabilitasyon ihtiyacı olabilir.

Hastaların mekanik ventilasyondan ayrılmasında pulmoner rehabilitasyon yaklaşımlarından yararlanılabilir²5. Gerekli durumlarda kişiye özgü sekresyonları atma ve dispneyi gidermeye yönelik uygulamalar planlanabilir. Ayrıca hastanede yatış döneminde yapılan yüzüstü pozisyonlama kaynaklı basınç yaraları, brakial pleksusta yaralanmalar ve plantar fleksiyon kontraktürleri oluşabilir ${ }^{24,31}$. Post-akut dönemde bu problemlere yönelik yaklaşımlarla ilgili uygulamalar da düşünülebilir.

Ek olarak COVID-19'a eşlik eden komorbiditeler ve hastalı̆̆ın kardiyovasküler, pulmoner, muskuloskeletal ve sinir sistemleri üzerindeki etkileri de dikkate alınmalıdır ${ }^{23,25}$. Fizyoterapi ve rehabilitasyon yaklaşımlarının uygulanmasından önce, hastanın hastanede yatış evresinde varsa aritmi, miyokardit gibi kardiyak problemlerinin düzeldiğinden emin olunmalı ve sonra uygulama yapılmalıdır 29 . Postakut COVID-19 olgularında fizyoterapi ve rehabilitasyon gereksinimleri ve 
rehabilitasyonun etkinliği ile ilgili bilgiler arttıkça, güncel önerilerde de değişiklikler yapmak gerekebilecektir.

\section{Sonuç ve Öneriler}

COVID-19 hastalığında sınıflandırmaya göre özellikle pnömoni, ciddi pnömoni ve ARDS evrelerinde solunum sisteminin önemli şekilde etkilendiği görülmektedir. COVID-19 hastalığında özellikle nefes darlığı, öksürük, kas ağrısı ve yorgunluk semptomları nedeniyle uygun olan hastalarda, uygun zamanda fizyoterapi ve rehabilitasyon yaklaşımları gerekebilir. Hastane döneminde, nefes darlığının belirti ve semptomlarını azaltmak, kaygıyı gidermek ve işlevi en üst düzeye çıkarmak için pulmoner rehabilitasyondan yararlanılabilir. Bununla birlikte rehabilitasyon, yüksek yaşam kalitesini korumak ve iyileşmeyi sağlamak için hastanede kalmanın ötesine taşınmalıdır. Genel bağlamda öncelikle hastalar detaylı bir şekilde değerlendirilmeli ve hedefler belirlenmeli, sonra ise uygun bireyler tespit edilip hedefler doğrultusunda bireye özgü rehabilitasyon yaklaşımları planlanmalıdır.

Ayrıca COVID-19 hastalığının akut aktif evresi bittikten sonra, uzun vadeli taburculuk döneminde henüz ne ölçüde sekel kalacağı veya fonksiyonların ne şekilde etkileneceğine ilişkin yeterli bilgi bulunmadığı için, post-akut dönemde de çeşitli sebeplerle fizyoterapi ve rehabilitasyon ihtiyacı doğabilecektir.

\section{KAYNAKLAR}

1. Huang C, Wang Y, Li X, et al. Clinical features of patients infected with 2019 novel coronavirus in Wuhan, China. Lancet. 2020;395(10223):497-506.

2. World Health Organization. Coronavirus disease (COVID-19) pandemic. https://www.who.int/emergencies/diseases/novel-coronavirus-2019 Erişim Tarihi 9 Ağustos 2020.

3. World Health Organization. Coronavirus Disease 2019 (COVID-19) Technical Guidance. https://www.who.int/health-topics/coronavirus\#tab=tab 1. Erişim Tarihi 9 Ağustos 2020.

4. COVID-19 (SARS-CoV2) Enfeksiyonu Rehberi (Bilim Kurulu Çalışması). T.C. Sağlık Bakanlığı. Halk Sağlığı Genel Müdürlüğü. T.C. Sağlık Bakanlığı. 
https://covid19bilgi.saglik.gov.tr/depo/rehberler/COVID-19 Rehberi.pdf. Erişim Tarihi 12 Ağustos 2020.

5. Baud D, Qi X, Nielsen-Saines K, Musso D, Pomar L, Favre G. Real estimates of mortality following COVID-19 infection. Lancet Infect Dis. 2020;20(7):773

6. Colbenson GA, Johnson A, Wilson ME. Post-intensive care syndrome: impact, prevention, and management. Breathe (Sheff). 2019;15(2):98-101.

7. Davidson JE, Harvey MA, Bemis-Dougherty A, Smith JM, Hopkins RO. Implementation of the pain, agitation, and delirium clinical practice guidelines and promoting patient mobility to prevent post-intensive care syndrome. Crit Care Med. 2013;41(9 Suppl 1):S136-45.

8. Chen J, Wu J, Hao S, et al. Long-term outcomes in survivors of epidemic Influenza A (H7N9) virus infection. Sci Rep. 2017;7(1):17275-82.

9. Batawi S, Tarazan N, Al-Raddadi R, et al. Quality of life reported by survivors after hospitalisation for Middle East respiratory syndrome (MERS). Health Qual Life Outcomes. 2019;17(1):101-107.

10. Jin YH, Cai L, Cheng ZS, et al. A rapid advice guideline for the diagnosis and treatment of 2019 novel coronavirus (2019-nCoV) infected pneumonia (standard version). Mil Med Res. 2020;7(1):4-26.

11. Guo YR, Cao QD, Hong ZS, et al. The origin, transmission and clinical therapies on coronavirus disease 2019 (COVID-19) outbreak - an update on the status. Mil Med Res. 2020;7(1):11-20.

12. Rodriguez-Morales AJ, Cardona-Ospina JA, Gutierrez-Ocampo E, et al. Clinical, laboratory and imaging features of COVID-19: A systematic review and metaanalysis. Travel Med Infect Dis. 2020;34:101623-35.

13. Tian Y, Rong L, Nian W, He Y. Review article: gastrointestinal features in COVID19 and the possibility of faecal transmission. Aliment Pharmacol Ther. 2020;51(9):843-851. 
14. Chen H, Guo J, Wang C, et al. Clinical characteristics and intrauterine vertical transmission potential of COVID19 infection in nine pregnant women: a retrospective review of medical records. Lancet. 2020;395(10226):809-815.

15. Borges do Nascimento IJ, Cacic N, Abdulazeem HM, et al. Novel coronavirus infection (COVID-19) in humans: A scoping review and metaanalysis. $J$ Clin Med. 2020;9(4):941-954.

16. COVID-19 Türkiye Web Portalı. https://covid19.tubitak.gov.tr/turkiyededurum. Erişim Tarihi 10 Ağustos 2020.

17. World Health Organization. Clinical management of severe acute respiratory infection (SARI) when COVID-19 disease is suspected. WHO Reference number WHO/2019-nCoV/clinical/2020.4. Interim Guidance. Erişim Tarihi 10 Ağustos 2020.

18. Singhal T. A review of coronavirus disease-2019 (COVID-19). Indian J Pediatr. 2020;87(4):281-286.

19. Vaira LA, Salzano G, Deiana G, De Riu G. Anosmia and ageusia: common findings in COVID-19 patients. Laryngoscope. 2020;130(7):1787.

20. Wu P, Duan F, Luo C, et al. Characteristics of ocular findings of patients with coronavirus disease 2019 (COVID-19) in Hubei Province, China. JAMA Ophthalmol. 2020;138(5):575-578.

21. Kooraki S, Hosseiny M, Myers L. Gholamrezanezhad A. Coronavirus (COVID19) outbreak: what the department of radiology should know. J Am Coll Radiol. 2020;17(4):447-451.

22. Thomas P, Baldwin C, Bissett B, et al. Physiotherapy management for COVID-19 in the acute hospital setting: recommendations to guide clinical practice. $J$ Physiotherapy. 2020;66:73-82.

23. Türkiye Fizyoterapistler Derneği. COVID-19 enfeksiyonunda fizyoterapi ve rehabilitasyon.https://drive.google.com/file/d/1iwzxxxVVCMUI27Ug74Wl1bR PbogEkYni/view. Erişim Tarihi 12 Ağustos 2020. 
24. Lazzeri M, Lanza A, Bellini R, et al. Respiratory physiotherapy in patients with COVID-19 infection in acute setting: a position paper of Italian Association of Respiratory Physiotherapists. Monaldi Arch Chest Dis. 2020;90(1):163-168.

25. Vitacca M, Carone M, Clini E, et al. Joint statement on the role of respiratory rehabilitation in the COVID-19 crisis: the Italian position paper. Respiration. 2020;99(6):493-499.

26. İnal İnce D, Vardar Yağlı N, Sağlam M, Çalık Kütükcü E. COVID-19 enfeksiyonunda akut ve post-akut fizyoterapi ve rehabilitasyon. Turk $J$ Physiother Rehabil. 2020;31(1):81-93.

27. Yin S, Huang M, Li D, Tang N. Difference of coagulation features between severe pneumonia induced by SARS-CoV-2 and nonSARS-CoV-2. $J$ Thromb Thrombolysis. 2020:1-4.

28. Aytür YK, Köseoğlu B, Taşkıran Ö, et al. SARS-CoV-2 (COVID-19) sonrası pulmoner rehabilitasyon prensipleri: Akut ve subakut sürecin yönetimi için rehber. Fiziksel Tip ve Rehabilitasyon Bilimleri Dergisi. 2020;23(2):111-123.

29. Spruit MA, Holland AE, Singh SJ, Troosters T. Report of an AdHoc International Task Force to develop an expert-based opinion on early and shortterm rehabilitative interventions (after the acute hospital setting) in COVID-19 survivors.https://ki.instructure.com/courses/4193/files/412565?module item id=87723 Erişim Tarihi 1 Nisan 2020.

30. Hsieh MJ, Lee WC, Cho HY, et al. Recovery of pulmonary functions, exercise capacity, and quality of life after pulmonary rehabilitation in survivors of ARDS due to severe influenza A (H1N1) pneumonitis. Influenza Other Respir Viruses. 2018;12(5):643-8.

31. McNeary L, Maltser S, Verduzco-Gutierrez M. Navigating coronavirus disease 2019 (COVID-19) in physiatry: a CAN report for inpatient rehabilitation facilities. PMR. 2020;512-515.

32. Mikkelsen ME, Shull WH, Biester RC, et al. Cognitive, mood and quality of life impairments in a select population of ARDS survivors. Respirology. 2009;14(1):76-82. 
33. Marra A, Pandharipande PP, Girard TD, et al. Co-occurrence of post-intensive care syndrome problems among 406 survivors of critical illness. Crit Care Med. 2018;46(9):1393-1401.

34. Vanhorebeek I, Latronico N, Van den Berghe G. ICU-acquired weakness. Intensive Care Med. 2020;46(4):637-53.

35. Gandotra S, Lovato J, Case D, et al. Physical function trajectories in survivors of acute respiratory failure. Ann Am Thorac Soc. 2019;16(4):471-7.

36. Luyt CE, Combes A, Becquemin MH, et al. REVA study group. Long-term outcomes of pandemic 2009 influenza $\mathrm{A}(\mathrm{H} 1 \mathrm{N1})$-associated severe ARDS. Chest. 2012;142(3):583-92.

37. Herridge MS, Tansey CM, Matté A, et al. Canadian critical care trials group. Functional disability 5 years after acute respiratory distress syndrome. $N$ Engl $J$ Med. 2011;364(14):1293-304. 